\title{
Genealogy of the Royal House
}

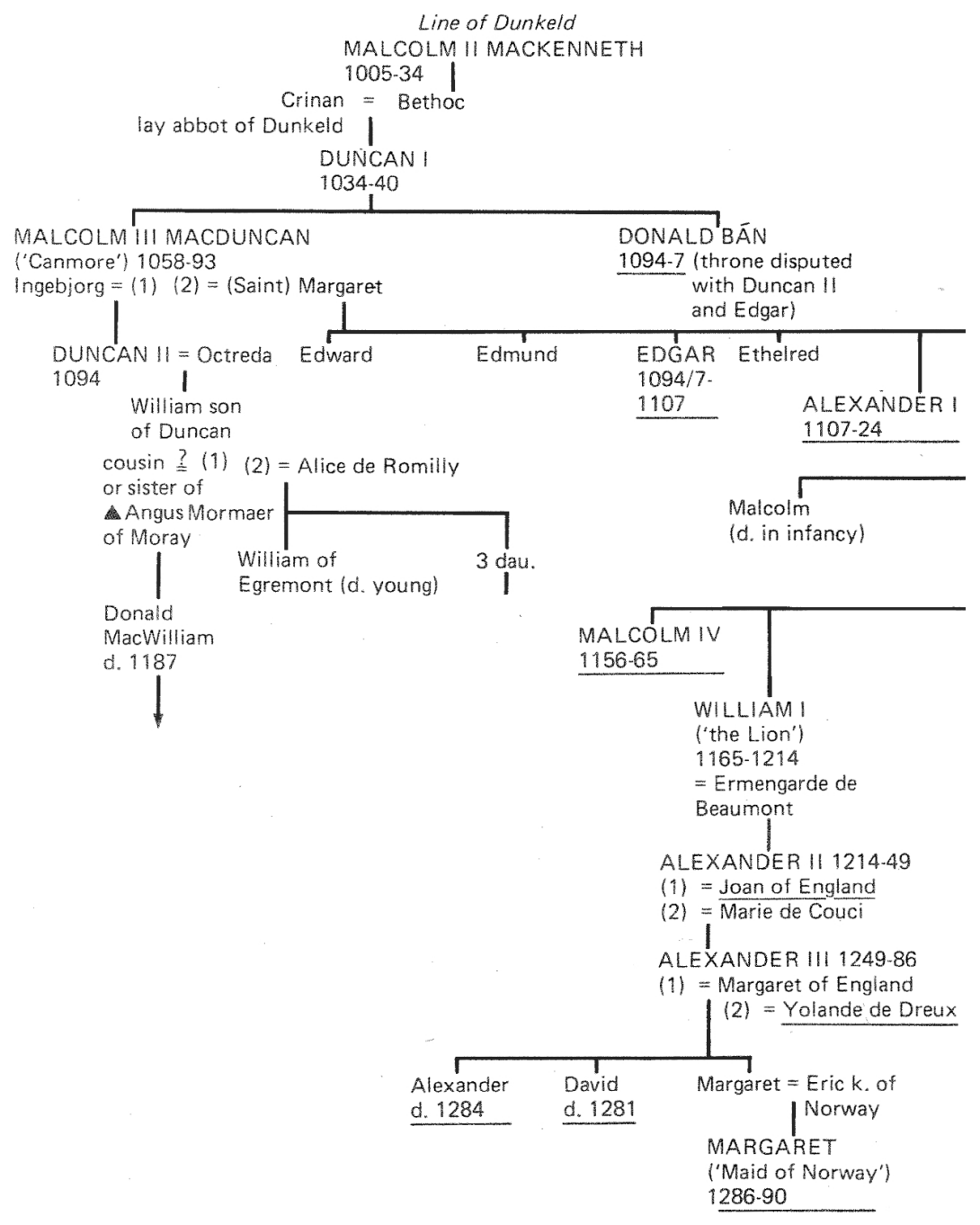




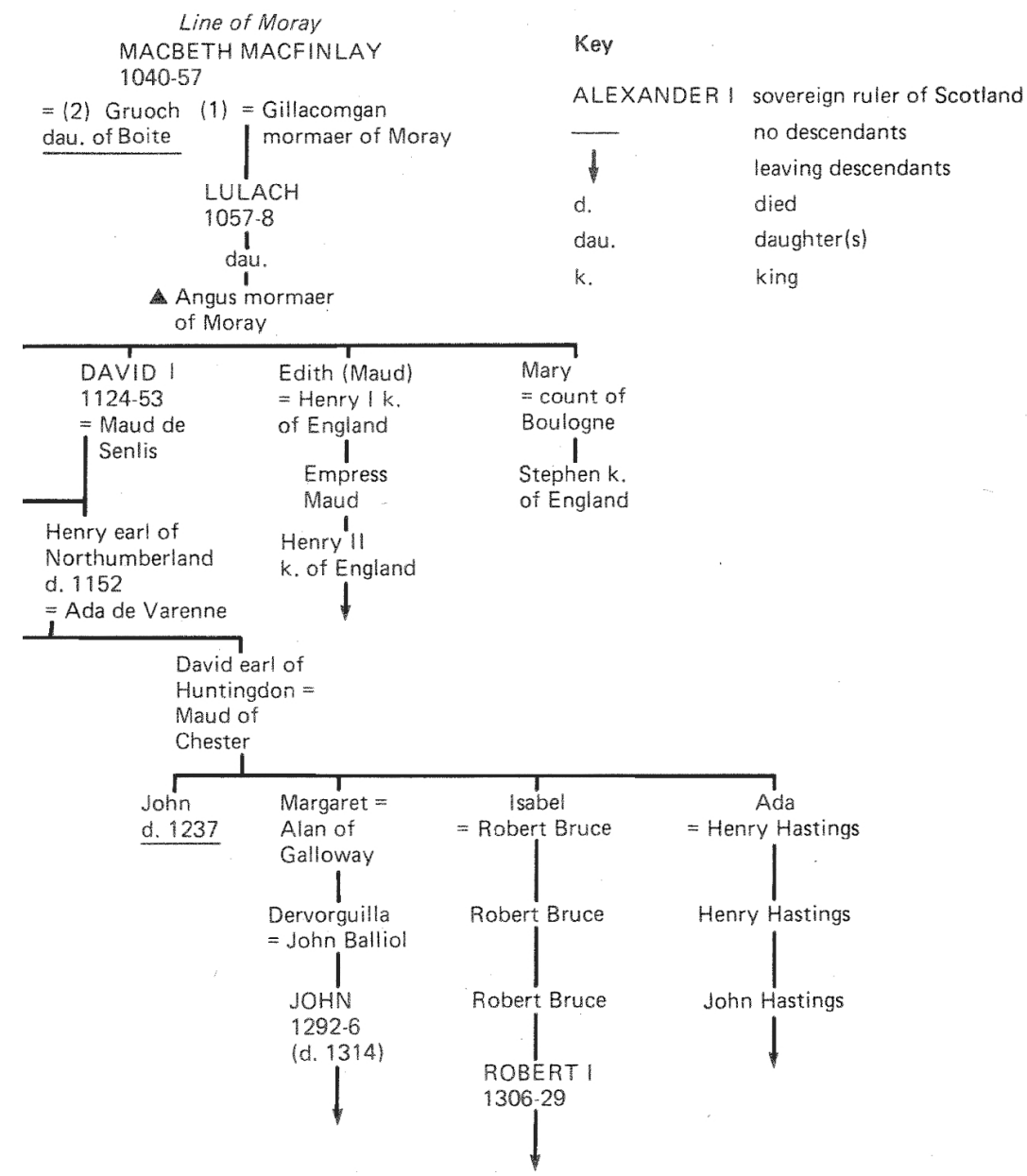


